\title{
US plans large funding boost to support nanotechnology boom
}

[WASHINGTON] The US government plans to launch a major, inter-agency nanotechnology initiative to nurture what officials describe as explosive growth in scientific interest in the behaviour of materials at the nanometre scale.

The National Science Foundation (NSF), which supports most university research in nanoscience and is likely to lead the initiative, reports that it can fund only 13 per cent of the grant applications it receives in the field, compared with the 40 per cent success rate in many disciplines at the agency.

Competition for funds in the field is "absolutely ferocious," says Stan Williams, head of basic research at Hewlett-Packard and a keen supporter of the initiative. Williams prefers the term nanoscience to nanotechnology because the latter term has become tarred by fanciful claims on its behalf.

"Part of the problem is that nanotechnology has been over-hyped," he says, noting that "we have to fight against the distaste" that some feel, associating the term with visions of a factory housed in a matchbox.

Instead, a growing understanding of materials at the nanometre scale, where dimensions are comparable to the lengths of individual molecules, is likely to transform large-scale products and processes. "This doesn't need to be about small things, it could be about parts in a car," explains Mike Roco of the NSF's engineering directorate, who chairs an inter-agency working group that is planning the initiative. "The utilization of nanotechnology is very broad, but all fields of it use the same tools and methods."

Perhaps the most commercially spectacular application so far is the use of giant magnetoresistance - discovered in 1988 - in the reading heads of most computer disk drives. The related phenomenon of tunnelling magnetoresistance will shortly allow the production of fast and compact randomaccess memories for computers.

But, as Williams points out, imminent applications of nanotechnology extend far beyond the computer industry. Kodak, he says, is developing nanoscale particles called 'dygments' - a cross between powder pigments and molecular dyes - for use in printing images. Tyre manufacturers plan to mix nanoparticles of clay with tyre rubber, tying up loose ends of polymer molecules and greatly extending tyre life. And the fourfifths of possible drug therapies that can't be tested in patients because they are insoluble in water could be produced as nanoparticles sitting in a suspension in water, and could

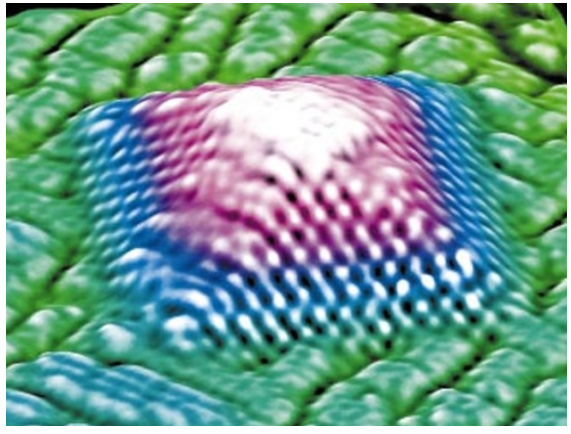

Small can be profitable: a 'quantum dot' of germanium atoms, $10 \mathrm{~nm}$ across.

therefore become viable therapy candidates.

All of this potential is attracting attention in Washington, where support for a research initiative is growing. In the annual budget guidelines circulated to agencies in May, Jack Lew, the director of the Office of Management and Budget at the White House, and Neal Lane, director of its Office of Science and Technology Policy, identified nanotechnology as an area ripe for special interagency attention. Last month, hearings in both the House and the Senate outlined the special potential of the field.

All of this points to the inclusion of a major nanotechnology initiative in the budget proposal for the 2001 fiscal year, which President Bill Clinton presents to the Congress next February. A report soon to be released by the inter-agency group calls for the initiative to double government spending on nanotechnology research from $\$ 250$ million to $\$ 500$ million over three years. Officials involved in planning the initiative hope that Clinton himself will announce it, possibly as early as September.

The NSF will spend $\$ 80$ million this year on nanotechnology research, while the Department of Defense spends $\$ 60$ million and the Department of Energy \$54 million. These figures suggest that total US government spending has doubled since 1997, when a study by the World Technology division of Loyola College estimated total government spending at $\$ 116$ million. Japan spent \$128 million in 1997 and Western Europe $\$ 120$ million, according to the study. But Rico says that spending in each region of the world has grown sharply since then.

"The European Union, Germany and Japan each have very focused efforts in nanotechnology," Williams says, adding that the US government research effort has lacked coordination, so that "some areas of research are being ignored completely".

However, the Loyola study found that the United States led the world in the synthesis and assembly of nanostructures, and in highsurface-area materials. It shared the lead with Europe in coatings and biological applications, while Japan led in 'nanodevices' and consolidated materials.

ColinMacilwain
[NEW DELHI] The Indian government has announced that it intends to convene a meeting of the country's top scientists to draw up a national plan of action to implement recommendations endorsed by the World Conference on Science, which ended in Budapest last week.

The recommendations are included in two documents, Declaration on Science and the Uses of Scientific Knowledge and Science Agenda: Framework for Action. These were unanimously endorsed by delegates at the end of the six-day meeting, which was jointly organized by the United Nations Educational, Scientific and Cultural Organization (Unesco) and the International Council for Science (ICSU) (for full report, see pages 100 and 101).

The Indian action plan will be submitted to the Unesco general conference in October, according to Muril Manohar Joshi, India's minister for science, who led the country's delegation in Budapest.
At a press conference in New Delhi, Joshi said that India was pleased with the outcome of the conference, and especially with the widespread support it received for its proposals for protecting traditional knowledge systems, compensating developing nations for the loss they suffer through the brain drain, and the possible regular publication of a World Technology Report.

Given that India's proposals on these topics had been adopted, Joshi said that the country would make a concentrated effort to ensure that steps are taken, in consultation with other countries in the region, to put into practice the principles and guidelines contained in the two final documents.

"We will immediately start those activities for which external support is likely to become available," says Valangiman Ramamurthi, secretary to the Department of Science and Technology. K. S. Jayaraman 